\title{
Measuring for Absorption: How the Institutionalisation of EU Cohesion Policy Influences the Use of Performance Indicators in Hungary
}

\author{
Károly Mike ${ }^{1}$, Gábor Balás
}

\begin{abstract}
We investigate the performance measurement of the implementing agencies of EU Structural Funds in Hungary. Following the advice of Thiel and Leeuw (2002), we focus on the incentives created by the institutional environment of these agencies. The core of this environment is a double principal-agent relationship between the European Commission (EC), the national government and the Managing Authority. We investigate its institutional features and the resulting organisational incentives for Managing Authorities in Hungary. Relying on programme evaluations, we explore how these incentives actually affected the design and use of performance measurement by Authorities in two policy fields: active labour-market policy and higher education. We find that external incentives to focus on absorption and formal compliance created bias against integrating performance measurement into the policy process and tackling problems of performance risk and non-measurability.
\end{abstract}

\section{Keywords:}

performance measurement, institutional analysis, project management, European Union, Structural Funds.

\section{Introduction}

The Structural Funds of the European Union have played a major role in bringing performance measurement to the public sectors of Central and Eastern European countries, including Hungary. Although indicator-based performance management exists in sporadic forms in the public administrations of these Member States

1 His work on this study was supported by the Bolyai Postdoctoral Scholarship of the Hungarian Academy of Sciences and the Hungarian Scientific Research Fund (project number PD 113072). 
(Nemec and Sagat 2011; Hajnal and Ugrósdy 2015), the regulations of EU Funds require the production of indicators of a scale and quality that far exceeds these other practices. The novelty of EU Funds in performance measurement is underscored by the administrative traditions of the region that emphasise legalism at the expense of efficiency (Hajnal and Jenei 2007). Compared to most "older" Member States, the significance of Funds is also amplified by their much greater share within the public budget. In the period 2007-2013, the average share of Structural Fund allocations within government capital expenditure was $37 \%$ in EU12 while merely $4 \%$ in EU15, according to the estimates of the European Commission (EC 2013a).

The arrival of Structural Funds may be seen as a welcome opportunity for this region of Europe to gain experience with advanced forms of performance management. Performance indicators can help ensure a more efficient use of public resources (OECD 1996) and support evidence-based policy-making (Boaz and Nutley 2009). Assisted by the European Commission, this is a benevolent, if perhaps coercive, instance of policy transfer. By contrast, sceptics of the worldwide proliferation of measurement techniques may point to their dangers. Long lists of "dysfunctions" and "diseases" of performance measurement may be quoted, suggesting that it may actually worsen rather than improve performance in any meaningful sense (Bouckaert and Balk 1991; Thiel and Leeuw 2002). Whether the positive or negative scenario prevails, depends, among other things, on the organisational context and the institutional environment in which performance measurement is carried out (Thiel and Leeuw 2002). This prompts us to investigate how the institutions governing the implementation of EU cohesion policy influence the design and use of performance indicators.

The complexity and cross-country variation of the institutions of EU cohesion policy may seem forbidding (cf. Molle 2008). The literature on "multi-level governance" argues that the policy field is characterised by fluid, network-type policymaking, including a plethora of actors at several levels of government (Marks 1996; Bache 2007). Even if only the formal management structures of Structural Funds are considered, they appear highly complex and byzantine (Wostner 2008; Ferry et al. 2007). Nonetheless, we believe that it is possible to focus on a limited set of institutions that are most likely to influence performance measurement in this field. The key impetus to use performance indicators comes from the adoption of quantified EU-level objectives adopted in high-level agreements, such as the Agenda 2020 or the Lisbon Treaty. These are reflected and expanded in national "reference frameworks", signed between the European Commission and each Member State. These frameworks consist of Operational Programmes (OP), each of which has its own set of indicators, purportedly to track its contribution to national objectives. Member States must set up an implementing agency - called Managing Authority - for each OP. This agency is responsible for monitoring the progress and ensuring the fulfilment of indicators (EC 1997). 
Thus, a double principal-agent (PA) relationship is at the heart of the implementation process of cohesion policy. As Blom-Hansen (2005) and Bauer (2006) argued, the relationship between the European Commission and the national government can be perceived as an agency relationship. The Commission has the task of ensuring that Member States follow EU regulations and fulfil their contractual promises laid down in the Operational Programmes. The national government further delegates implementation to the Managing Authorities and thereby creates a second, lower-level principal-agent relationship. In our institutional analysis, we focus on this double PA structure.

We follow the approach of new institutional economics in perceiving institutions as "rules of the game" (North 1990) that create incentives for human action. A comprehensive institutional analysis would need to discuss both rules within the organisations responsible for performance measurement and the external rules of their institutional environment. Although future analysis should consider intra-organisational issues, we here restrict our attention to the latter and consider Managing Authorities as "black boxes". Thus, we formulate two research questions:

1) What incentives are created by the double PA relationship between the European Commission, the national government and the Managing Authority that influence the last-named organisation's decisions about the design and use of performance measurement?

2) How are these incentives reflected in the actual practice of performance measurement within Managing Authorities?

\section{Methodology}

We restrict our attention to a single country with which we are particularly familiar: Hungary. The case-study method is justified by our interest in a qualitative analysis of institutional mechanisms. Although we cannot validate our findings for other Member States, we believe that the main institutional issues are similar, at least where EU Funds weigh as heavily in the public budget as in Hungary. The external incentive structure of implementing agencies is reconstructed on the basis of legal regulations, political and administrative documents as well as the secondary analysis of existing empirical literature on cohesion policy. Since all Managing Authorities in Hungary were institutionalised in essentially the same way, we provide an analysis that is valid for all of them.

As for answering the second research question about the actual effects of institutional incentives, we focus on two policy fields where large amounts of Funds were used: active labour-market programmes and higher education. Substantial amounts of EU Funds have been spent on virtually all policy areas in Hungary, and it would be impossible to cover all of them in sufficient institutional detail. The examined programmes belong among the "softer" measures of cohesion policy focussed on 
human and economic development as opposed to more traditional, "hard" tools aiming at infrastructure development. While the latter certainly remain substantial and would require additional analysis, the former have been gaining importance, as has been clear from EU-level strategies and guidelines for some time (EC 2010).

Our evidence about the actual practice of performance measurement is based on two evaluations of development programmes, commissioned by the National Development Agency of Hungary. ${ }^{2}$ Each evaluation covered all forms of financial support assigned from Structural Funds to interventions in one policy area between 2006 and 2012: active labour-market services and higher education, respectively. The underlying idea was to examine how EU funds were able to contribute to the broad strategic goals of the policy field. The evaluations used mixed empirical methodology, including (i) the analysis of programme documents, relevant legal texts, public databases and other written information sources; (ii) interviews with top policy makers and officials responsible for programme design as well as implementation and policy experts; (iii) case studies based on field work in higher education institutions and providers of active labour-market services; and (iv) an online national survey among non-profit employment service providers. ${ }^{3}$

Although the evaluations did not enable us to conduct a fully-fledged process tracing (Gerring 2007), they provided evidence whether the observed practice of performance measurement by Managing Authorities was consistent with the external incentives of these organisations. Moreover, document analysis and expert interviews revealed if these external incentives indeed showed up in the considerations leading to the adoption of observed practices.

\section{External incentives for the implementing agencies of Structural Funds in Hungary}

The organisational incentives of a Managing Authority are shaped by its principalagent relationship with the national government. The goals and actions of the government as a principal are, in turn, influenced by its higher-level PA relationship with the Commission. In other words, the higher-level PA contract constrains the lower one. As a first step, we analyse the characteristics of the former and the incentives they provide for the national government. As a second step, we examine

2 The programme evaluations were commissioned by the National Development Agency of Hungary, the highest governmental body responsible for the planning and implementation of cohesion policy and conducted between February 2012 and March 2013 by the Hétfa Research Institute, an independent private organisation, in collaboration with the Revita Foundation. The evaluations are accessible online in Hungarian at http://palyazat.gov.hu/human_fejlesztesek ertekelesei (last accessed 30 July 2015). Executive summaries in English can be downloaded at http://palyazat.gov.hu/download/48706/Executive_Summary_Employability_Eval.pdf and http://palyazat.gov.hu/download/48114/Executive_\%20Summary_Eval_Higher_Education_ Programmes.docx (last accessed 30 July 2015).

3 No such survey was conducted among higher-education institutions. 
how these incentives influence the characteristics of the government's lower-level PA contract and the Managing Authority's resulting incentives.

\subsection{The PA relationship between the European Commission and the national government}

The institutionalisation of cohesion policy reflects the perennial concern of Member States to strike a balance between preserving their sovereignty and enabling the European Commission to coordinate and enforce common policies effectively (Doleys 2000, Tallberg 2003). The organisation of the policy field is based on what legal and administrative scholars call the "principle of limited powers" (Siedentopf and Speer 2003). National governments retain the right to decide on the size of Fund budgets for periods of 5 or 7 years as well as their allocation among Member States. ${ }^{4}$ They also bear the primary responsibility for planning and implementing the programmes on which national allocations are spent. The Commission plays a role as a coordinator and supervisor of the spending of Funds. Parallel to the decision-making process on fund allocation, the Commission proposes EU-level objectives and general administrative rules for the Funds. Once the allocations are made and these rules are adopted by national representatives, the Commission translates them into formal contracts with Member States, nowadays called "National Strategic Reference Frameworks" that consist of "Operational Programmes" devoted to broad policy fields or regions. The Commission negotiates and accepts these contracts and subsequently monitors their implementation by national governments. PA relationships between the Commission and national governments are thus created.

The Commission has neither mandate nor resources to get involved in substantive policy issues during the implementation of the Operational Programmes. It has no right to withhold or reallocate allocated Funds either, except for cases of serious procedural irregularities. Thus, its role is largely confined to enforcing stringent formal obligations about process and output (Bachtler and Mendez 2007). Its contract with each Member State defines (i) explicit performance indicators, (ii) rules for the Member State's internal procedures of monitoring and reporting to ensure the supply of credible information about the indicators adopted, and (iii) procedures of financial control and auditing to prevent the fraudulent diversion of funds. In short, it takes the form of a performance contract which specifies quantified measures or "indicators" of performance and, at the same time, defines procedures for the agent to provide credible information about these measures.

Although the Commission cannot sanction the non-fulfilment of indicators with monetary penalties, it has two powerful means to enforce the contract. One is its right to suspend the payment of funds if administrative irregularities are suspected. The reliable collection of data for indicators is one such requirement (EC

4 Recently, the European Parliament has been given rights of co-decision. Nonetheless, the key decision is made in the Council by representatives of national governments. 
2013b). Moreover, the number and complexity of administrative prescriptions is immense, which provides the Commission with considerable discretion in exercising this right. The second method is the naming and shaming of Member States based on a detailed monitoring of their performance and making the non-fulfilment of contractual obligations public (Tallberg 2003; Zängle 2004).

The primary measure the Commission uses to compare countries and policy areas in its interim evaluations is the rate of absorption, i.e. the percentage of funds spent (EC 2012; EC 2013a). This seems a peculiar choice since spending in itself has little to do with actual performance. However, the same phenomenon was observed in the field of foreign aid to developing countries (Edgren et al. 1996; Svensson 2006). The explanation there was that the outcomes and effects of aid programmes can only be measured imperfectly and in the longer term, while political donors (and their voters) demand quick and easy-to-digest feedback about the use of funds. In a similar way, Brussels is expected to verify its competence in supervising the spending of Funds by Member States (Molle 2008). Absorption rate is used as a very imperfect measure of how far each country has travelled in implementing its Operational Programmes.

Thus, the Commission creates incentives for the national government to comply with formal procedural obligations and ensure timely absorption. Its demands are backed up by its ability to hold back funds and apply reputational sanctions. Although there may be tension between the Commission's two goals (since absorption would be quickest without any imposed rules), they have one thing in common: neither pertains to the substantive outcomes or effects of the financed programmes.

The national government must implement its contract with the Commission in its domestic political environment, which will also influence its incentives. On the hand one, absorption may become a political issue, especially when the Funds' contribution to the national budget is very large. The government must prove that no money will be "lost" due to its incapability of organising the proper management of funds. On the other hand, electoral concerns, interest-group pressure or other domestic factors may provide incentives to use EU-funded programmes to achieve substantive, rather than merely formal, policy objectives. This is especially likely if EU funds are large enough to influence politically salient goals, such as reduction in unemployment, improving public health care, etc. There may, again, be tension between the two incentives since quick absorption may come at the expense of effectiveness.

Overall, the Commission's and domestic political expectations are likely to provide a strong incentive for the national government to focus on absorption. Since the Commission ties absorption to strict compliance with formal procedural requirements, this also implies a strong incentive for formal compliance. If timely spending is the government's paramount concern, it is likely to consider the production of contracted indicators as a means to this end, too. They will be expected 
to serve the performance of formal contractual obligations rather than the better performance of the financed programmes in terms of efficiency, effectiveness or any other normatively defensible criteria. Domestic political concerns that mitigate the pressure to absorb have no clear implications for the design and use of indicators. However, they at least make room for the possibility that the government may be interested in using performance measurement as a tool to improve the effectiveness of EU-funded programmes in achieving substantive policy objectives.

If we look at the empirical evidence on the actual goals of Hungary's government in spending EU Funds between 2006 and 2013, we observe that absorption became a salient political issue from early on and only grew more important as time progressed. As an internal memorandum of the (left-wing) government made clear in 2008, "the (political) measure of success both externally [by the European Commission] and internally [in Hungary] will be the degree of absorption (since effectiveness can be judged only after some time)." In 2012, the prime minister (now from the political right) agreed: "Every single cent of the EU funds has to find its way to its destination and we will not accept any compromise in this". ${ }^{5}$ Basically all reports and evaluations agree that absorption and the regularity of spending were the primary goals of cohesion policy in Hungary as it was implemented both between 2004 and 2006 and between 2007 and 2013. ${ }^{6}$

Although absorption was a political "trump-card", governments also wanted the funds to contribute effectively to their policy goals. The framework contract for the period 2007/2013, signed with the Commission, was widely marketed by the government as the "New Hungary Development Plan" which ought to support several policy goals. ${ }^{7}$ After a change in government in 2010, this expectation grew markedly stronger as the government introduced its own new development plan for reinvigorating the economy after the financial crisis $^{8}$ (called New Széchenyi Plan, named after a great Hungarian $19^{\text {th }}$-century statesman), which was financed entirely by EU Funds. By "repackaging" the programmes co-financed by the EU and placing it high on its political agenda, the government increased its political commitment to spending the funds in ways that further its own substantive policy goals. In fact, it could hardly have done otherwise. It had little non-EU resources to finance anything beyond the basic routine activities of the public sector. Hungary's prime minister claimed in 2012 that "90 per cent of all funds spent on development in

5 Reported on the government's website on 19 July, 2012. See: http://eu.kormany.hu/nincs-magyar-fejlesztespolitika-unios-forrasok-nelkul (last accessed 30 July, 2015).

6 For example Hungarian State Audit Office (2006; 2011), KPMG (2011), Perger (2009).

7 See, e.g., the Prime Minister's remarks in 2007 in the press about the Development Plan's importance to long-term strategic goals: http://stop.hu/belfold/gyurcsany-az-umft-nem-lett-politikaicsatarozasok-aldozata/185882/ (last accessed 30 July 2015).

8 Between 2009 and 2010, Hungary had a caretaker government with little political autonomy. So political response to the financial crisis (which was mainly a crisis of the public budget in Hungary) was somewhat delayed until after the next parliamentary elections. 
Hungary come from the European Union."9 Such a magnitude was supported by the calculations of the European Commission about the share of ERDF and Cohesion Fund allocations in government capital expenditure: $67.4 \%$ for the $2007-2013$ period - compared to an average $4 \%$ in EU15 and $37 \%$ in EU12. The share of funds remaining for the years 2013-2015, when payment was still allowed, was even higher: $87.7 \%$ (EC 2013a). But "development" is a broader concept than capital outlays: EU funds played an immense role in virtually all budgetary measures beyond the automatic basic financing of government activities and even as replacements of such financing. As we shall illustrate below, they were used to filling gaps in ordinary (non-development) budgetary appropriations, which decreased significantly as a result of drastic austerity measures put in place by the national government after $2010 .{ }^{10} \mathrm{EU}$ funds were seen in 2006 - not unreasonably - as "free money that was additional to sectoral budgets." Consequently, existing sectoral policies could be pursued largely independent of EU funds. As a result of the fiscal crisis leading to austerity, the situation changed: the government had to realise that "EU funds are virtually the only sources available for any policy initiatives." ${ }^{11}$

All in all, absorption had high political salience and remained the overriding concern of Hungarian governments throughout the entire period. Policy effectiveness remained secondary but gradually increased in importance, especially after national budgetary resources ebbed due to recession and austerity. The next step in our analysis is to explore how this influenced the government's actions in shaping the lower-level PA relationships with Managing Authorities.

\subsection{The PA relationships between the national government and its Managing Authorities}

Although EU regulations determine many details, national governments have substantial autonomy in choosing which existing or newly created organisations fulfil the roles of Managing Authorities, and how they are organised. The national government can use its discretion to shape its PA relationships with these agencies in ways that reflect its own objectives.

The literature stresses two dimensions in which governments use their autonomy: (1) their place in the territorial hierarchy of government ${ }^{12}$ (Hooghe and Marks 2003), and (2) their embeddedness in national public administration (Taylor et al. 2000; Ferry et al. 2007; Thielemann 2002). While the first dimension is usually considered important because cohesion policy is supposed to further "regionalisation",

9 http://eu.kormany.hu/nincs-magyar-fejlesztespolitika-unios-forrasok-nelkul (last accessed 30 July 2015).

10 As shown by OECD's Economic Outlook (2013), Hungary reduced the budget deficit by 8.25 percentage-points from 2006/2007 to 2012/2013, surpassed only by Greece in this period.

11 Quotations from an interview with a high-level government official.

12 Often referred to as the effect of cohesion policy on "regionalisation". 
it is virtually a non-issue in Hungary as it opted for a very centralised system, with marginal roles for organisations at the regional (NUTS 2) level. Thus, we focus on embeddedness. In this dimension, comparative studies of national implementation systems emphasise the crucial choice between pre-existing organisations integrated in national public administration and newly created agents specialising on cohesion policy, what Ferry et al. (2007) call "integrated" and "differentiated" systems of implementation, respectively. ${ }^{13}$ In the ideal-type of an integrated system, the roles of Managing Authorities are filled by existing organisations within various sectoral (e.g. health, economic development) or functional (e.g. finance) or subnational administrations. In a differentiated system, a wholly new and specialised network of organisations dedicated to cohesion policy may be created (Ferry et al. 2007). Real systems tend to fall between these two clear-cut extremes. ${ }^{14}$

If the government's key concern is the absorption of funds, it will want an agent to focus on this goal in a single-minded fashion. It should set this as the overarching organisational goal for the implementing agent, to be achieved by pursuing the subordinated goals of timely spending, no irregularities and the production of contracted indicators. A straightforward option is to create a single-purpose organisation dedicated solely to programmes financed from EU funds. By contrast, if the government wants the agent to consider programme aspects which are not to be reported to the Commission but are important for the government's policy goals, the agent's organisational goals should include these other aspects as well. A natural choice is to assign implementation to an integrated agency which is responsible for overall policy effects in a certain policy field or regional area. As a corollary, a differentiated system would use performance indicators mainly as instruments of absorption, whereas an integrated system would be more likely to use them, at least partly, as instruments of policy effectiveness.

In 2006, Hungary opted for a differentiated and highly centralised system of implementation. It united all Managing Authorities (MAs) in a separate ministry called the National Development Agency and made them responsible for the design, monitoring and evaluation of Operational Programmes. The system was separated as much as possible from pre-existing parts of public administration. This is perhaps most clearly reflected in the Hungarian habit of referring to all EU-funded projects as measures of "development policy" (fejlesztéspolitika), viewed as an independent policy field.

The radical differentiation of the management of EU Funds was partly a response to the perceived difficulties of the partially integrated system put in place after Hungary's accession to the EU (Heil 2013). In that system, Managing Authorities

13 Taylor et al. (2000) propose a similar typology by distinguishing between "subsumed" and "differentiated" systems.

14 Hybrid systems are referred to as "composite" (Taylor et al. 2000) or "aligned" (Ferry et al. 2007). 
were integrated into ministries as ordinary departments. The main problems were the slowness of implementation and the proliferation of tendering and contracting procedures. What was demanded by potential beneficiaries and their political representatives was "simplification, standardisation and acceleration" (Heil 2013, 38). The institutional system was designed so that its central goal and success criterion would be the smooth implementation of Operational Programmes rather than contributing to any specific substantive policy goals. It was acknowledged from the start that it would be challenging to channel sufficient sectoral expertise into implementation and to coordinate EU-funded projects with nationally financed activities (Heil 2013). Nonetheless, the institutional setup was designed to give priority to absorption and regular implementation.

The system set up in 2006 was kept in place after a change in government in 2010 despite far-reaching institutional reforms in many segments of the public sector. As the programming period progressed, absorption remained the most important political measure of success for the National Development Agency. The opening page of its website contained an "absorption meter", giving real-time feedback on the amount of EU Funds spent to date. When its president left office in 2013, the government evaluated his performance in the public solely in terms of absorption rates. ${ }^{15}$

After 2010, the role of sectoral ministries in the design (but not the implementation) of individual financing constructions was somewhat strengthened. They became responsible for "preparing the professional content of financing constructions" and "following the professional aspects of tendering calls and strategic projects". ${ }^{16}$ Hence, they were given a stronger say in the professional content of project designs while the entire institutional system of implementation was kept in place. This can be interpreted as a small step towards an integrated model. Overall, the institutional development of cohesion policy in Hungary reflected the government's primary objective of absorption and only a secondary (though growing) emphasis on policy effectiveness. The political concern for ensuring absorption became institutionalised in the system of "single-purpose" implementing agencies, differentiated from the rest of public administration. The overriding organisational goal of Managing Authorities was absorption ensured by formal compliance with EU regulations. This suggests that, within their competence, implementing agencies would design and use performance indicators primarily to comply with the formal requirements of the Commission, before all other considerations. As a next step, we investigate if this was indeed the case in their actual practice in two fields of programmes: active labour-market policy and higher education.

15 As evidenced in the media coverage: http://www.origo.hu/gazdasag/20130429-tavozik-az-nfuvezetoje.html (last accessed 30 July 2015).

16 4/2011. (I. 28.) Governmental decree. 


\section{The practice of performance measurement by Managing Authorities}

Operational Programmes must be translated into project-form contracts signed with final beneficiaries. Managing Authorities must design and manage project systems so that they contribute to the performance of Operational Programmes as expressed in its official indicators. They must monitor in a verifiable way what projects accomplish. The system of monitoring must also follow and measure project-specific aspects of performance that are not captured by programme-level indicators. Overall, implementing agencies view performance indicators primarily as elements in the governance of project-form contracts with final beneficiaries.

In the general practice of EU cohesion policy, projects usually take two forms: competitive grant schemes and strategic projects (Wostner 2008). The former typically expect a multitude of final beneficiaries (lower-level public organisations, nonprofits, firms or even individuals) to carry out relatively small sets of tasks. Strategic projects tend to be signed with high-level public organisations (such as sectoral ministries, their national or regional agencies). These public bodies may use their own mechanisms of governance to allocate resources within a single large project, designed for the policy field, perhaps independently of EU funding. In such a case, the Managing Authority is responsible for performance measurement at the project level, while the financed public organisation may use its internal system of performance measurement (if there is one) within the project.

The design of projects takes place in several steps as broad Operational Programmes are divided into ever smaller parts until individual contracts are defined. Our empirical evidence suggested that we simplify the analysis of this process by defining only two levels: (i) the design of project systems, and (ii) the design of final project contracts. We examine the two levels in turn.

\subsection{The design of project systems}

Active labour-market policy. Structural Funds made up very significant parts in the financing of active labour-market policy between 2007 and 2013 in Hungary. As shown in Graph 1, labour-market programmes co-financed by Structural Funds gradually crowded out interventions financed from national sources. In some years, they accounted for over $50 \%$ of programme expenditure by the National Employment Fund, the main financing channel of such measures. 


\section{Graph 1}

Composition of the yearly (planned) budget of Hungary's National Employment Fund

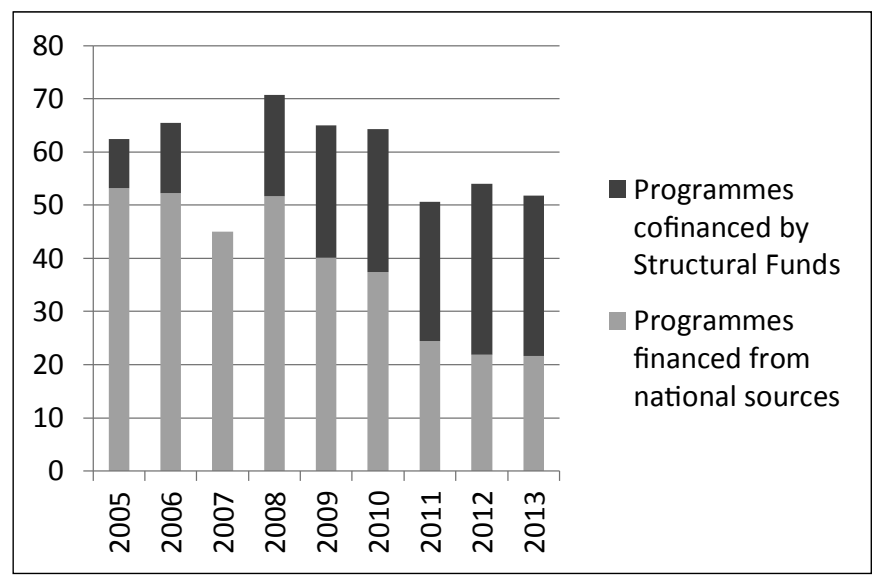

Published official budgetary plans of the Fund (no consistent data were available about implemented budgets.)

An important goal of the "Social Renewal Operational Programme" (SROP) was to increase the volume and quality of active labour-market policies. Following trends in Europe, both services provided "in-house" by the public employment service (PES) and "outsourced" to non-profit service providers were to be supported. In the examined period, the National Public Employment Service (PES) was the public organisation that bore primary responsibility for this field of public services. It was a multi-level network, consisting of ministerial oversight, a national office (National Labour Office), regional centres and local branch offices. ${ }^{17}$

The Managing Authority of SROP could have contracted with the national office (or the overseeing ministry) for one large strategic project and leave its implementation to the internal governance system of PES. This would have been a natural choice for several reason. PES had experience in providing such services; it had its own internal system of management and control; and it was in the process of developing it into an advanced system of management by objectives (financed - ironically, as we shall see - from EU funds; Hétfa and Revita 2013a). Alas, it did not happen. Instead of signing a comprehensive contract with PES and leaving its internal management to the organisation, the Managing Authority opted for a different solution. It signed separate contracts for three broad target groups: people with disabilities, people who have received social assistance, and unemployed peo-

17 Although the Service still exists, it was subsequently reorganised. Regional centres were decentralised into county-level centres, which became integrated as departments into comprehensive county-level government agencies. 
ple belonging to socially disadvantaged groups. ${ }^{18}$ The strategic contracts defined subprojects for each region, making each regional PES centre directly responsible for keeping procedural obligations and fulfilling contracted indicators. Although experts of PES and its ministerial oversight were closely involved in the planning and professional control of regional projects as well as their coordination with nonEU-funded activities, the Managing Authority effectively circumvented the existing internal governance structure of PES. It did not have sufficient trust in the capability of the existing internal systems, which were themselves under development. It chose not to rely on its internal system of management and control. Nor did it accept its existing monitoring system for providing indicators but requested regional centres to set up a parallel system for EU-funded projects.

For the projects financing non-profit service providers, the contractual design was even more radical. The ministry proposed that these external providers should be financed through PES. Regional centres would decide about the mix of services and outsource to external providers what they could not efficiently produce in house. This corresponds to the usual international practice and the recommendations of the relevant literature (Bruttel 2005; van Berkel et al. 2012): coordination and professional control requires that external non-profit providers are contracted by the public organisation that is responsible for labour-market services. ${ }^{19} \mathrm{After}$ long discussions, the Managing Authority vetoed this solution. Instead, it announced open tendering calls for nonprofits directly through its Intermediate Body. The main reason for the MA's reluctance to rely on PES was the perceived lack of that organisation's capacities to contract for and manage external service provision. The MA had no trust in the ability of PES to handle complex and risky contracts with third parties in compliance with all relevant regulations. In effect, a new tendering system was created for non-profit service providers within the field of "development policy", which began to function parallel to and largely uncoordinated with the PES system. Performance indicators appeared as part of this parallel project system.

Higher-education policy. EU funds also greatly contributed to Hungary's higher education budget. As in employment policy, national budgetary appropriations for higher-education institutions decreased steadily in the period, while EU funds virtually poured into the sector, adding as much as 35 per cent in 2012 to yearly national budgetary support (Graph 2).

18 The contracts belong to the following measure of the Social Renewal Operating Programme: SROP 1.1. Development of the Employment Service and the Establishment of an Integrated System of Employment and Social Policy.

19 The professional debate revolves around the appropriate level (local, regional or national) to which contracting should be delegated. However, it is beyond discussion that organisations responsible for labour-market services should be the ones which do the outsourcing. 


\section{Graph 2}

Volume and composition of allocations to higher-education institutions (planned values)

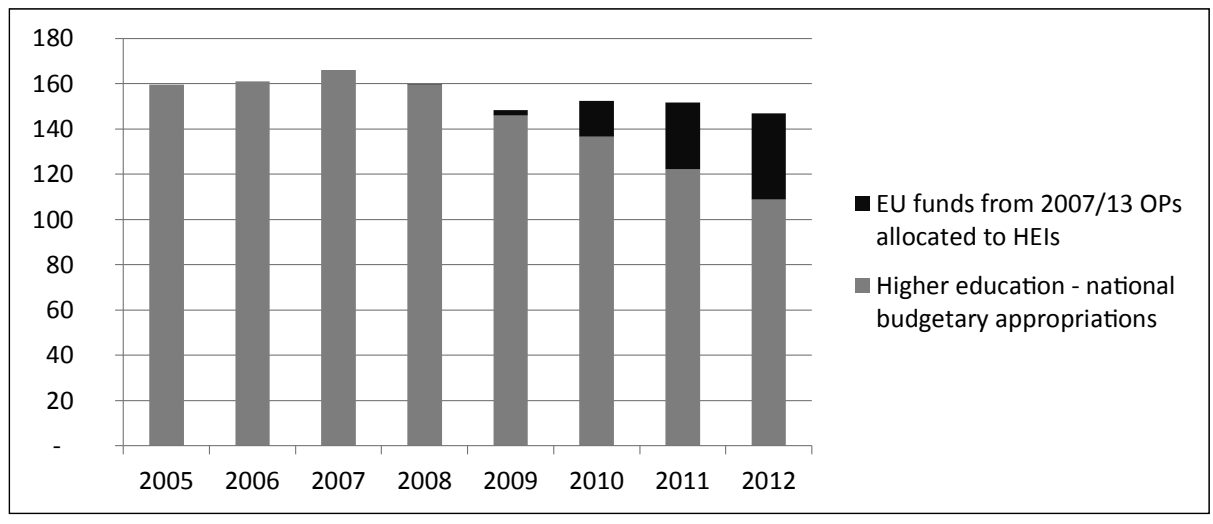

Data on EU Funds derived from the official monitoring database for Structural Funds in Hungary (EMIR), as of 31 December 2012. Data on national budgetary appropriations based on the annual Budgetary Acts of the Hungarian Parliament.

Most of the Fund sources were contracted in project form through a competitive call process, similar to the case of non-profit providers of active labour-market services. As in labour policy, a self-standing project system arose. Although the ministry responsible for higher education took an active part in designing the calls, they were not integrated into the national system of financing higher-education institutions but were managed separately in the differentiated sphere of "development policy". The efforts and failure of integration are best illuminated by the example of the so-called "research university projects".

In 2010, the ministry responsible for higher education announced a certification procedure for "research universities". ${ }^{21}$ The idea was taken from the German Excellence Initiative (launched in 2006), which awards extra funds in a competitive selection process to higher-education institutions which excel in high-quality research. Unlike the German system, the Hungarian ministry did not attach funding directly to the title but declared that certified research universities "may receive additional financial support in a separate procedure."22 However, this was not to be. Instead a call for tenders was issued by the responsible Managing Authority (through its Intermediate Body). The call was issued before the certification process ended, used different criteria and was eventually won by almost all Hungarian uni-

20 Financing measure SROP 4.2.1/B within the Social Renewal Operating Programme.

21 See http://www.nefmi.gov.hu/felsooktatas/archivum/kutatoegyetem-minosites (last accessed 30 July 2015).

22 1/D. §, 276/2009. (XII. 4.) Governmental decree. 
versities, several of which were not to receive certification as "research universities" (Hétfa and Revita 2013b). The project system created by this call was considered by all institutions to be a one-time and short-term affair from the beginning. It financed projects for two years with no promise of continuation (since even the future of cohesion policy in the EU after 2013 was uncertain at the time). It was not integrated into the national governance system of higher education, which could have given it permanence. The comparison with the German system is striking. There, the two most important and stable national organisations in research policy ${ }^{23}$ were given joint responsibility for running the Excellence Initiative. Three rounds were financed between 2006 and 2012, offering five-year contracts for the selected organisations. Ironically, the German federal government now believes that the main weakness of the Initiative is that it provides support in the form of "projects limited in time and topics" and is now planning to shift to more "permanent arrangements" to finance research excellence in higher education. ${ }^{24}$ How would they judge the Hungarian case? It would, of course, be wrong to put down the choice of a less-than-suitable contracting form simply to the myopia or incompetence of the Hungarian government. It was rather the direct result of the political emphasis on absorption and the institutionalisation of cohesion policy reflecting this emphasis (Hétfa and Revita 2013b).

The separated system of projects implied that a transient system of performance monitoring was set up only for these projects. It was managed outside the national governance of higher education by the Intermediate Body and the Managing Authority of the Operational Programme. As in the case of PES, universities had to provide data for this system, while existing systems of data collection were ignored. Although the Ministry of Education collected data on some aspects of performance and a Higher Education Information System was being developed at the time (Hajnal and Ugrósdy 2015), these systems were considered incapable of providing performance data in a reliable way.

In both labour-market and higher-education policy, performance measurement was institutionalised as part of a newly created and temporary project system, outside the existing national governance structure of the respective policy field. The sole reason for this institutional choice was the Managing Authority's endeavour to ensure compliance with the formal requirements of EU regulations and Hungary's contract with the European Commission. The potential to incorporate and utilise the performance indicators in the policy process (Bouckaert and Halligan 2008)

23 The German Research Foundation (Deutsche Forschungsgemeinschaft) and the German Council of Science and Humanities (Wissenschaftsrat). See www.dfg.de/en/research_funding/programmes/excellence_initiative/ (last accessed 30 July 2015).

24 See, e.g., the press release by the German Federal Ministry of Education and Research: Mehr Kooperation von Bund und Landern an den Hochschulen [More cooperation between the Federal Government and the States in Higher Education]. Available at http://www.bmbf.de/press/3291. php (last accessed 15 February 2014). 
was therefore heavily constrained by the absorption motive. Indicators were linked to short-term projects, and their "life" ended with the end of projects. Medium and long-term effects were by necessity ignored. Nor was there room for learning from the repeated (and possibly refined) use of indicators. ${ }^{25}$ Projects and indicators were handled by agencies dedicated to absorption rather than sectoral public organisations, pursuing, if imperfectly, substantive policy goals in their areas. Instead of building on and improving the performance-management systems of national public organisations, EU-funded programmes probably delayed their development. As we showed above (Graphs 1 and 2), the financing of both sectors shifted heavily towards EU sources. Inevitably, administrative efforts focused on the ad-hoc and transient systems of project instead of developing more permanent structures.

\subsection{Design of project contracts}

Within the constraints of project systems, performance indicators for individual projects could be used in a more or less sophisticated way. The available programme evaluations provide information on two important aspects of performance measurement: the handling of performance risks and non-measurable dimensions of performance (cf. Smith 1995; Thiel and Leeuw 2002).

Evaluations (Hétfa and Revita 2013a, 2013b) revealed that the usual practice was to take key indicators from the Operating Programmes and transpose them as obligatory performance targets into project contracts. (A few other indicators were added when the OP-level indicators seemed irrelevant or incomplete for the project.) Initially, financing was tied in a rather crude form to indicators: if a beneficiary did not produce a certain threshold value of the indicators on average, it had to pay the money back. This placed the entire risk of project performance captured by indicators on the beneficiary. The government played a "hot potato" game of riskshifting: the national government shifted the risks associated with the production of indicators to Managing Authorities, the latter to Intermediate Bodies, which shifted them further to the beneficiaries. As the programming period wore on, indicator risks materialised and threatened absorption. The government agencies responded by taking over part of the risk from project beneficiaries: indicator values could now fall below threshold levels to a certain extent, and funds would be lost only in proportion to the gap between actual and threshold values. However, interviews revealed that the change was not motivated by more efficient risk-sharing. The risks of beneficiaries were considered only so far as they threatened timely absorption because beneficiaries would throw back the hot potatoes of risky indicators by renouncing their contractual obligations and funds. In fact, Managing Authorities emphatically did not look upon indicators as either performance incentives or risksharing tools. They viewed them simply as obligations, imposed by the contract

25 One exception was when tendering calls were repeated (usually no more than 2 or 3 times) for the same circle of beneficiaries. 
between Commission and Member State, to which all benefitting actors should contribute roughly in proportion to the funds received (Hétfa and Revita 2013b).

Potential beneficiaries responded by promising indicator values that were as low as possible ex ante without endangering access to funds and structuring their activities ex post to minimise the risk of not fulfilling contracted indicator values. When their ex-ante strategy worked out well, indicators became mere administrative burdens (that could be very high, actually), without a distorting effect on the organisation's activities. This was the case for most indicators in several projects in higher education. Universities promised numbers of refereed publications or numbers of $\mathrm{PhD}$ students involved in research projects which could be easily fulfilled. When indicators were high enough to influence the behaviour of beneficiaries, highly risk-averse behaviour prevailed. Most non-profit beneficiaries in the field of active labour-market policy had to tailor their activities to fulfil indicator requirements (Hétfa and Revita 2013a). They refrained from truly innovative activities and "cherry-picked" their project locations, target groups and individual participants very cautiously. Although they were assumed to reach the most vulnerable social groups, they faced strong perverse incentives not do so.

Officials at Managing Authorities and Ministries providing professional advice usually paid careful attention to choosing appropriate project indicators. Nonetheless, the one-time nature of projects made it unreasonable to invest in designing sophisticated measures, monitoring them and demanding beneficiaries to supply them. Although the problem of non-measured aspects was often realised, the project system allowed little room to handle it. One exception was the appropriate design of selection procedures. By examining the previous performance of an applicant and its professional reputation, the probability for it to be capable and willing to perform well regardless of concrete indicators can be increased. Programme evaluations found some weak evidence that selection procedures preferred beneficiaries with better capabilities than their peers according to common professional standards in their field. Universities with improving publication records were more likely to attract bigger funds (Hétfa and Revita 2013b). Nonprofits with higher levels of rationalised organisation and professional competence were more likely to receive funds for active labour-market service provision (Hétfa and Revita 2013a).

Overall, the picture emerges that the overriding goal of project indicators was to ensure that the formal indicator targets of operational programmes would be reached. Although Managing Authorities were aware of performance risks and non-measured aspects of performance, they had neither room for, nor interest in handling these problems in but the most rudimentary ways. The organisations' external incentives that favoured absorption and formal compliance vis-à-vis the European Commission were clearly reflected in their decisions about the design and use of performance indicators at the project level. 


\section{Discussion}

Our first research question concerned the incentives created by the double PA relationship between the European Commission, the national government and the Managing Authority that influenced the last organisation's decisions about the design and use of performance measurement. An institutional analysis identified three major incentives for the national government due to its PA contract with the European Commission. The Commission as a principal had an interest in expecting formal compliance with procedural regulations, including the supply of verifiable performance indicators, as well as timely absorption of Funds. The importance of absorption was underlined by its political salience due to the relatively large size of Funds allocated to Hungary. In addition, domestic politics provided a third incentive: to use funds effectively to further substantive policy goals rather than mere absorption or formal compliance. Empirical evidence showed that in the period observed, absorption was the overriding goal for the Hungarian government. This was mainly a consequence of the political salience of absorption due to the very large volume of Funds and the administrative challenge of complying with elaborate EU procedures. Policy effectiveness remained a secondary goal, although it became somewhat more important, as the share of EU sources in the financed policy fields grew in a time of austerity.

The identified incentives influenced the government's behaviour in the lower-level PA relationships with Managing Authorities. Ensuring absorption was the single most important political expectation vis-à-vis the implementing agents. Even more important, this goal was reflected in the way agencies were institutionalised. They were organised as a newly created system differentiated and separated from existing public organisations that were responsible for the policy fields in which Funds were used. Ensuring formal compliance and absorption were set as the main organisational goals for them. Contribution to substantive policy goals remained a secondary and weak expectation throughout the period, despite growing awareness that coordination with sectoral ministries and national agencies would be desirable.

How were the external incentives actually reflected in the practice of performance measurement within Managing Authorities? The absorption and formal compliance incentives implied that performance measurement be employed chiefly to ensure the fulfilling of verifiable performance indicators for the European Commission. The programme evaluations provided detailed evidence that this was indeed the case in the two policy fields reviewed (active labour-market policy and higher education). First, ad-hoc systems of performance measurement were built outside the existing governance structures of the policy fields. Managing Authorities set them up parallel to existing systems that were centred on sectoral ministries and employed national budgetary sources. In principle, implementing agencies could have relied on the internal governance systems of existing national organisations (such as the national ministry or agency) for implementation and monitoring 
performance. However, they had no trust in these national organisations' capability to monitor and fulfil indicator requirements. As a negative consequence, the institutional setting precluded the emergence of non-transient systems of performance management that could have enabled the integration of formal measurement into policy cycles (Bouckaert and Halligan 2008).

Second, project-level indicators within the above-mentioned systems served the purpose of ensuring that programme-level indicators would be fulfilled in a verifiable way. Financing was linked to project indicators simply and directly. Distortions due to the riskiness of performance and its non-measurable dimensions were realised by officials but they were largely ignored, due to a lack of incentives and resources. Although sectoral administrations became involved in designing the professional content of projects, the indicator system remained unaffected, firmly in the hands of the Managing Authorities grouped in the National Development Agency.

Overall, our findings suggest that the institutions of cohesion policy exerted a rather unfavourable influence on performance measurement for EU Funds in Hungary. The strong incentives of absorption and formal compliance with EU regulations hindered the creation of a system of performance measurement that would handle measurement problems in a sophisticated way and be effectively integrated in the policy process. At the same time, our analysis also suggests under what conditions these negative effects might be mitigated. If funds are large enough to be truly vital for the relevant policy fields and implementing agencies are integrated into, rather than differentiated from, sectoral administrations, their politically imposed organisational goals are likely to shift from absorption towards policy effectiveness. Nonetheless, it seems safe to predict that, short of radical change in the underlying institutional rules of EU cohesion, absorption will remain a prominent goal, compromising the design and use of performance measurement for Structural Funds.

\section{References}

Bache, Ian. 2007. "Cohesion Policy." In Paolo Graziano and Maarten P. Vink (eds). Europeanization. New Research Agendas. Basingstoke: Palgrave Macmillan, 239-252.

Bachtler, John and Carlos Mendez. 2007. "Who Governs EU Cohesion Policy? Deconstructing the Reforms of the Structural Funds." Journal of Common Market Studies 45(3), 535-564.

Boaz, Annette and Sandra Nutley. 2009. "Evidence-Based Policy and Practice." In Tony Bovaird and Elke Loeffler (eds). Public Management and Governance. $2^{\text {nd }}$ edn. Abingdon: Routledge, 327-342. 
Bouckaert, Geert and Walter Balk. 1991. "Public Productivity Measurement: Diseases and Cures." Public Productivity \& Management Review 15(2), 229-235.

Bouckaert, Geert and John Halligan. 2008. Managing Performance: International Comparisons. New York: Routledge.

Bruttel, Oliver. 2005. "Contracting-out and Governance Mechanisms in the Public Employment Service." Wissenschaftszentrum Berlin für Sozialforschung (WZB), Forschungsschwerpunkt: Arbeit, Sozialstruktur und Sozialstaat, Abteilung: Arbeitsmarktpolitik und Beschäftigung, Discussion paper SP I 2005-109.

Doleys, Thomas J. 2000. "Member States and the European Commission: Theoretical Insights from the New Economics of Organization." Journal of European Public Policy 7(4), 532-553.

Edgren, Gus, Roger C. Riddell and Sobhan Rehman. Aid Dependency: Causes, Symptoms and Remedies. Stockholm: Swedish International Development Agency.

European Commission. 2013a. Expert Evaluation Network Delivering Policy Analysis on the Performance of Cohesion Policy 2007-2013: Synthesis of National Reports 2012. Brussels: European Commission.

European Commission. 2013b. Programming Period 2014-2020: Monitoring and Evaluation of European Cohesion Policy. European Social Fund. Guidance document (draft), 9 January. Brussels: European Commission. Available at http://ec.europa.eu/social/BlobServlet?docId=7884\&langId=en (last accessed 30 July 2015).

European Commission. 2012. Expert Evaluation Network Delivering Policy Analysis on the Performance of Cohesion Policy 2007-2013: Synthesis of National Reports 2011. Brussels: European Commission.

European Commission. 2010. Investing in Europe's Future: Fifth Report on Economic, Social and Territorial Cohesion. Brussels: Europan Commission.

European Commission. 1997. Evaluating EU Expenditure Programmes: A Guide. Ex Post and Intermediate Evaluation. Brussels: European Commission.

Ferry, Martin, Frederike Gross, John Bachtler and Irene McMaster. 2007. “Turning Strategies into Projects: The Implementation of 2007-13 Structural Funds programmes." IQ-Net Thematic Paper 20(2). Glasgow: European Policies Research Centre.

Gerring, John. 2007. Case Study Research: Principles and Practice. Cambridge: Cambridge University Press. 
Hajnal, György and György Jenei. 2007. "The Study of Public Management in Hungary: Management and the Transition to Democratic Rechtsstaat." In W. J. M. Kickert (ed.). The Study of Public Management in Europe and the United States: A Comparative Analysis of National Distinctiveness. London: Routledge, 208-232.

Hajnal, György and Márton Ugrósdy. 2015. Use and Utilization of Performance Information in Hungary: A Comparative Case Study of a Local Government and the Higher Education Sector. Corvinus University of Budapest. Manuscript.

Heil, Péter. 2013. “A kohéziós politika megvalósítása Magyarországon” [The implementation of cohesion policy in Hungary]. In Sándor Gyula Nagy (ed.). Európai uniós támogatások, pályázatírás és menedzsment [EU funds, tendering, and management]. Corvinus University of Budapest. Manuscript.

Hétfa Research Institute and Revita Foundation. 2013a. A foglalkoztathatóság javítását szolgáló intézkedések értékelése [Evaluation of programmes targeting the improvement of employment]. Evaluation report. Budapest: National Development Agency. Full text in Hungarian available at http://palyazat.gov.hu/foglalkoztathatosag_javitasat_szolgalo_intezkedesek_ertekelese. Summary in English available at http://palyazat.gov.hu/download/48706/Executive_Summary_Employability_Eval.pdf (last accessed 30 July 2015).

Hétfa Research Institute and Revita Foundation. 2013b. A felsőoktatást célzó programok értékelése [Evaluation of programmes targeting higher education]. Evaluation report. Budapest: National Development Agency. Full text in Hungarian available at http://palyazat.gov.hu/a_felsooktatast_celzo_programok_ertekelese. Summary in English available at http://palyazat.gov.hu/ download/48114/Executive_\%20Summary_Eval_Higher_Education_Programmes.docx (last accessed 30 July 2015).

Hooghe, Liesbet and Gary Marks. 2003. "Unraveling the Central State, but How? Types of Multi-Level Governance." American Political Science Review 97(2), 233-243.

Hungarian State Audit Office [Állami Számvevőszék]. 2011. Jelentés a Nemzeti Fejlesztési Terv végrehajtásának értékeléséröl [Report on the evaluation of the implementation of National Development Plan]. Report 1110.

Hungarian State Audit Office [Âllami Számvevőszék]. 2006. Jelentés a Nemzeti Fejlesztési Terv végrehajtásának értékeléséröl [Report on the evaluation of the implementation of National Development Plan]. Report 0636.

KPMG. 2011. Az operatív programok félidei értékeléseinek szintézise [Synthesis of mid-term evaluations of operational programmes]. Available at http://www. nfu.hu/a_felidei_ertekelesek_szintezise_2007_2013 (last accessed 30 July 2015). 
Marks, Gary. 1996. "Exploring and Explaining Variation in EU Cohesion Policy." In Liesbet Hooghe (ed.). Cohesion Policy and European Integration: Building Multi-Level Governance. Oxford: Oxford University Press, 367-387.

Molle, W. 2008. European Cohesion Policy. London: Routledge.

Nemec, Juraj and Vladimir Sagat. 2011. "Performance Management in CEE: What can we Learn from Existing Experience?” Paper presented at the 2011 ECPR General Conference in Reykjavík, Iceland, 25-27 August 2011. Available at http://ecpr.eu/filestore/paperproposal/17d7a451-c55e-4c84-8c64-22c4e7cb547c.pdf (last accessed 30 July 2015).

North, Douglass C. 1990. Institutions, Institutional Change and Economic Performance. Cambridge: Cambridge University Press.

OECD. 2013. OECD Economic Outlook 2013(1). Available at http://www.oecd-ilibrary.org/economics/oecd-economic-outlook-volume-2013-issue-1_eco_ outlook-v2013-1-en (last accessed 30 July 2015).

OECD. 1996. Performance Auditing and the Modernisation of Government. Paris: Organization for Economic Cooperation and Development Press.

Perger, Éva. 2009. EU kohéziós támogatások felhasználásának intézményrendszere és a forrás-felhasználás hatékonysága, eredményessége [Efficiency and effectiveness in the institutionsal system and allocation of EU cohesion funds]. Budapest: ECOSTAT. Available at http://www.kozigkut.hu/doc/perger_09szept. pdf (last accessed 30 July 2015).

Siedentopf, Heinrich and Benedikt Speer. 2003. "The European Administrative Space from a German Administrative Science Perspective." International Review of Administrative Sciences 69, 9-28.

Smith, Peter C. 1995. "On the Unintended Consequences of Publishing Performance Data in the Public Sector." International Journal of Public Administration 18(2-3), 277-310.

Svensson, Jakob. 2006. "Absorption Capacity and Disbursement Constraints." In: Financing Development: What are the Challenges in Expanding Aid Flows? Proceedings of the $3^{\text {rd }}$ AFD-EUDN Conference, 2005. Paris: Agence Française de Développement, 73-98.

Tallberg, Jonas. 2003. European Governance and Supranational Institutions: Making States Comply. London: Routledge.

Taylor, Sandra, John Bachtler and Marie-Louise Rooney. 2000. "Implementing the New Generation of Programmes: Project Development, Appraisal and Selection." IQ-Net Thematic Paper 7(2) Glasgow: European Policies Research Centre. 
Thiel, Sandra van and Frans L. Leeuw. 2002. "The Performance Paradox in the Public Sector." Public Performance and Management Review 25(3), 267-281.

Thielemann, Eiko R. 2002. “The Price of Europeanization: Why European Regional Policy Initiatives Are a Mixed Blessing." Regional and Federal Studies 12(1), $43-65$.

Van Berkel, Rik, Fritz Sager and Franziska Ehrler. 2012. "The Diversity of Activation Markets in Europe." International Journal of Sociology and Social Policy 32(5), 273-285.

Wostner, Peter. 2008. “The Micro-Efficiency of EU Cohesion Policy." IQ-Net Thematic Paper 64. Glasgow: European Policies Research Centre.

Zängle, Michael. 2004. “The European Union Benchmarking Experience: From Euphoria to Fatigue?" European Integration online Papers (EIoP) 8(5). Available at http://eiop.or.at/eiop/texte/2004-005a.htm (last accessed 30 July 2015). 